Acta vet. scand, $1986,27,486-496$.

From the Department of Animal Genetics and the Department of Veterinary Physiology and Biochemistry, Royal Veterinary and Agricultural University, Copenhagen, Denmark.

\title{
MITOGEN STIMULATION OF LYMPHOCYTES IN PIGS WITH HEREDITARY VITAMIN C DEFICIENCY
}

\author{
By \\ Birte Kristensen, Preben Dybdahl Thomsen, Birthe Palludan \\ and Inger Wegger
}

KRISTENSEN, BIRTE, PREBEN DYBDAHL THOMSEN, BIRTHE PALLUDAN and INGER WEGGER: Mitogen stimulation of lymphocytes in pigs with hereditary vitamin $C$ deficiency. Acta vet. scand. 1986, 27, 486-496. - Recently an inherited vitamin C deficiency in the pigs presumably based on an autosomal recessive gene was decribed. Homozygotes are in contrast to heterozygotes and normal pigs unable to synthesize ascorbic acid. In an experiment comprising 3 littermate pigs, 2 homozygous and 1 heterozygous for the vitamin $\mathrm{C}$ deficiency gene, the influence of ascorbic acid depletion and repletion on mitogen stimulation of peripheral blood lymphocytes was studied. Ascorbic acid depletion of the vitamin $\mathrm{C}$ dependent pigs resulted in a rapid decline in plasma ascorbic acid. Response of lymphocytes to stimulation with Concanavalin A (Con A) and phytohemagglutinin M (PHA) decreased more slowly reaching a minimum, which coincided with the occurrence of the first clinical symptoms of scurvy. Following resupplementation with vitamin $\mathrm{C}$ the plasma content of ascorbic acid rapidly returned to normal, while the lymphocyte response to Con A and PHA stimulation only gradually approached the initial values. The repletion with ascorbic acid caused a transitory increase in the response to pokeweed mitogen (PWM) stimulation. The significance of these findings in relation to the cellular immune system in normal pigs is discussed.

mitogenstimulation; blood ly mphoytes; as corbic acid; Con A; PHA; P W M.

Pigs are not expected to require exogenous vitamin $\mathrm{C}$ since they can synthesize ascorbic acid in the liver. Nevertheless supplementation with ascorbic acid has in some cases been shown to augment growth rate and feed efficiency (Yen \& Pond 1981, Brown 1984). Several studies also indicate that ascorbic acid increase the resistence to infectious diseases in various farm ani- 
mals (cf. Kolb 1985). The reasons for these beneficial effects are not known. However, part of the explanation could be that ascorbic acid enhances the immune defense of the animals. As reviewed by Anderson (1984) ascorbic acid seems to be important for optimal function of the cellular immune system, and various components of this system may be stimulated by ingestion of vitamin C even in subjects with presumably "normal" ascorbic acid status. Whether the humoral immune response is also influenced by ascorbic acid is less clear. Some experiments have shown increased antibody production following administration of vitamin C to man (Prinz et al. 1977) and calves (Blair \& Cummins 1984), while no effect was seen in others (Anderson $e^{t}$ al. 1980).

Recently an inherited vitamin C deficiency, presumably based on an autosomal recessive character has been discovered in swine (Jensen et al. 1983). Pigs homozygous for the gene lack Lgulonolactone oxidase activity and, hence, cannot synthesize ascorbic acid. If not supplemented with the vitamin their plasma ascorbic acid concentration declines rapidly and they develop clinical symptoms of scurvy within a few weeks. On the other hand the heterozygous carriers of the trait have normal plasma ascorbic acid contents and show no deficiency symptoms.

While the influence of suboptimal ascorbic acid status on the immune system of normal pigs is difficult to study, pigs with hereditary vitamin $\mathrm{C}$ deficiency are excellent for such experiments. Furthermore, since the pig from a physiological point of view is closer related to man than are rodents it could be a relevant animal model for studying human metabolic dysfunctions. Thus, basic investigations elucidating the effect of vitamin $\mathrm{C}$ on the immune response carried out in pigs with the above mentioned defect might offer several advantages as compared to such studies in guinea pigs.

The purpose of the experiment presented here was to study the responsiveness of lymphocytes to mitogens in vitamin $\mathrm{C}$ dependent pigs during a depletion and repletion period.

\section{MATERIALS AND METHODS}

\section{Animals}

A litter from a sow homozygous for the vitamin C deficiency gene and a heterozygous boar was subjected to short term ascorbic acid deprivation and the content of ascorbic acid in 
plasma from the pigs was determined. Based on results of this test 2 vitamin $\mathrm{C}$ dependent homozygotes (one male no. 916 and one female no. 921) and 1 heterozygote (male no. 919) were selected for the present study at the age of $2 \frac{1}{2}$ months. The animals were fed twice a day with a commercial, pelleted pig feed, which was practically devoid of ascorbic acid. The homozygous pigs were initially supplemented with 2 grams of ascorbic acid per day $(2 \times 1 \mathrm{~g})$. The vitamin in crystalline form was mixed with the ration just before feeding. At day zero of the experiment the vitamin $\mathrm{C}$ supplementation was discontinued and all animals were fed the ascorbic acid free diet until the homozygotes developed symptoms of scurvy, i.e. leg weakness, unwillingness to move and inappetence. The deficient pigs were then treated with a daily i.m. injection of $0.5 \mathrm{~g}$ ascorbic acid for 4 days and simultaneously the oral supplementation with the vitamin was resumed.

\section{Lymphocyte cultures}

Heparinized blood samples were collected from the V. cava cranialis before morning feeding on days $0,7,14,35,42,61$ and 90 during the experiment.

For the mitotic index assay lymphoid cells were cultured for $72 \mathrm{~h}$ at $38^{\circ} \mathrm{C}$ by adding aliquots of $0.3 \mathrm{ml}$ whole blood to $4.0 \mathrm{ml}$ RPMI 1640 (Flow supplemented with $10 \%$ fetal calf serum (Ercopharm), heparin (5 IU/ml), streptomycin $(100 \mu \mathrm{g} / \mathrm{ml})$, penicillin $(100 \mathrm{IU} / \mathrm{ml})$, Fungizone $(2 \mu \mathrm{g} / \mathrm{ml}$, Squibb) and $0.1 \mathrm{ml}$ phytohemagglutinin M (PHA, Wellcome). One hour prior to harvest the cultures were incubated with colcemid (Fluka) in a final concentration of $0.8 \mu \mathrm{g} / \mathrm{ml}$. The procedure for preparation of metaphase spreads was as described by Christensen \& Pedersen (1982). Mitotic indices were calculated from a cell count of $3 \times 2000$ mononuclear cells. Mitotic index prior to vitamin $\mathrm{C}$ deprivation was set to $100 \%$ and relative mitotic indices of the test cultures were calculated accordingly.

For the mitogen stimulation assays the stabilized blood was diluted 1:4 in Hanks' balanced salt solution (HBSS) and lymphocytes were isolated on a Ficoll gradient (sp. gr. 1.077, Pharmacia) by centrifugation at $500 \times \mathrm{g}$ for $30 \mathrm{~min}$ at $18^{\circ} \mathrm{C}$. The lymphocyte layer was removed and washed twice with HBSS by centrifugation at $150 \times \mathrm{g}$ for $10 \mathrm{~min}$. Recovered lymphocytes were suspended in RPMI 1640 supplemented as mentioned above. The 
cell concentrations were adjusted to $3.0 \times 10^{6}$ cells $/ \mathrm{ml}$ and cultured in micro tissue culture plates (Teknunc). To triplicate cultures $\left(450 \times 10^{3}\right.$ cells/well) $50 \mu \mathrm{l}$ (final concentration $40 \mu \mathrm{g} / \mathrm{ml}$ ) of concanavalin A (Con A, Pharmacia) or pokeweed mitogen (PWM, Sigma, final concentration $30 \mu \mathrm{g} / \mathrm{ml}$ ) dilutions were added. Cultures were incubated at $38^{\circ} \mathrm{C}, 5 \% \mathrm{CO}_{2}$ and $100 \%$ relative humidity for $48 \mathrm{~h}$. Six hours before harvesting $50 \mu \mathrm{l}$ of methyl- ${ }^{3} \mathrm{H}$ thymidine (final activity $6 \mu \mathrm{Ci} / \mathrm{ml}$ ) was added. Filter discs (Flow) were prepared for liquid scintillation and counted in a beta-counter. Results of the stimulation of lymphocytes were expressed as counts per minute (cpm).

\section{Hematology}

All blood samples were subjected to routine hematology including total and differential leucocyte counts at the Central Laboratory of the University.

\section{Plasma ascorbic acid}

Blood samples taken at the time intervals mentioned above and stabilized with $\mathrm{K}_{2}$ EDTA were used for the determination of plasma ascorbic acid concentration by means of a modification of Bessey's method (Bessey 1938, Lund 1980).

\section{RESULTS}

Withdrawal of the ascorbic acid supplement resulted in a rapid decline in plasma ascorbic acid concentration of the 2 homozygous pigs (nos. 916 and 921) within 1 week (Fig. 1). Clinical symptoms of scurvy were evident in these animals at day 14 of the experiment and hence the ascorbic acid treatment was resumed from that date. This resulted in an almost immediate alleviation of the symptoms and after 3-4 days the pigs were apparently fully restituted.

Following the deprivation of ascorbic acid the ${ }^{3} \mathrm{H}$-thymidine uptake in Con A stimulated lymphocytes from the homozygous pigs gradually decreased reaching a minimum at day 14 (Fig. 2). Similar results were obtained in PHA stimulated cell cultures (results not shown). The mitotic index, also representing PHA stimulation, was likewise reduced in these pigs and also reached a minimum at day 14 of the experiment (Fig. 3). The very low response to Con A and PHA stimulation of the lymphocyte cul- 


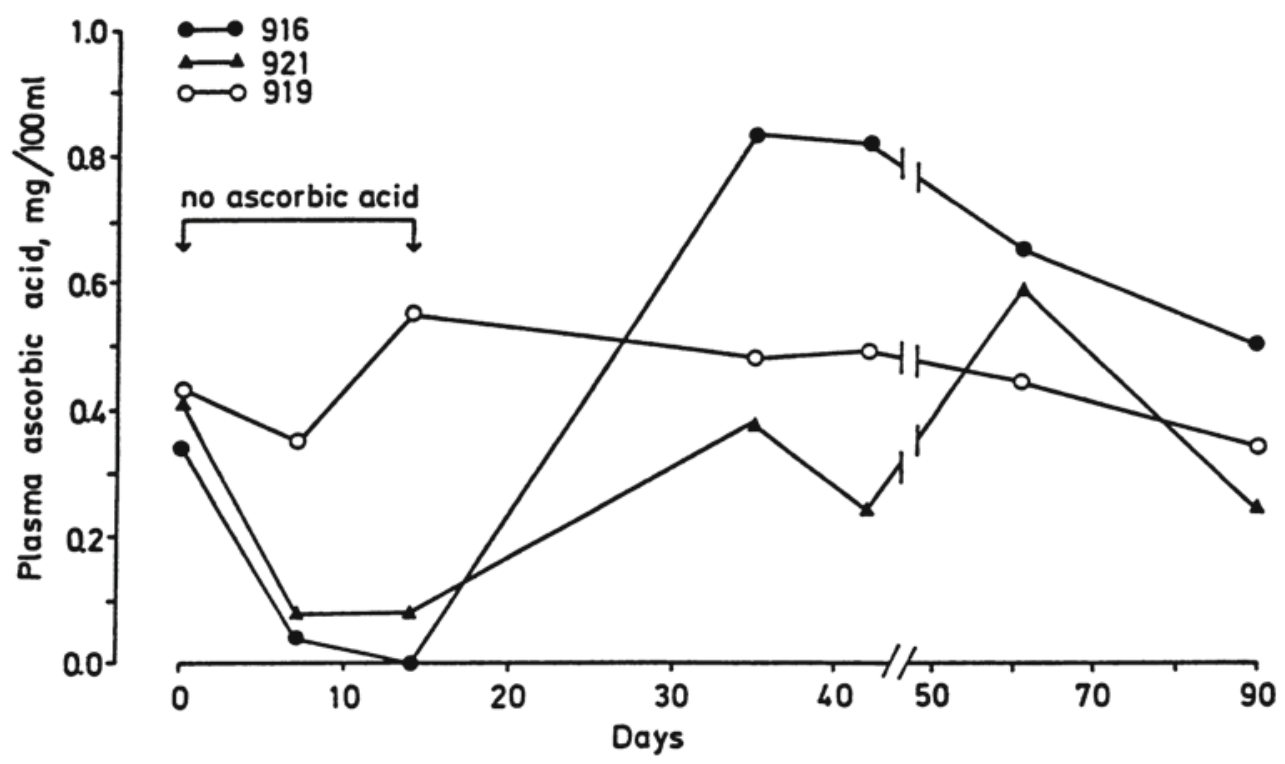

Figure 1. Changes in plasma ascorbic acid during the experimental period. Pigs nos. 916 and 921 are homozygous and no. 919 is heterozygous for the deficiency gene.

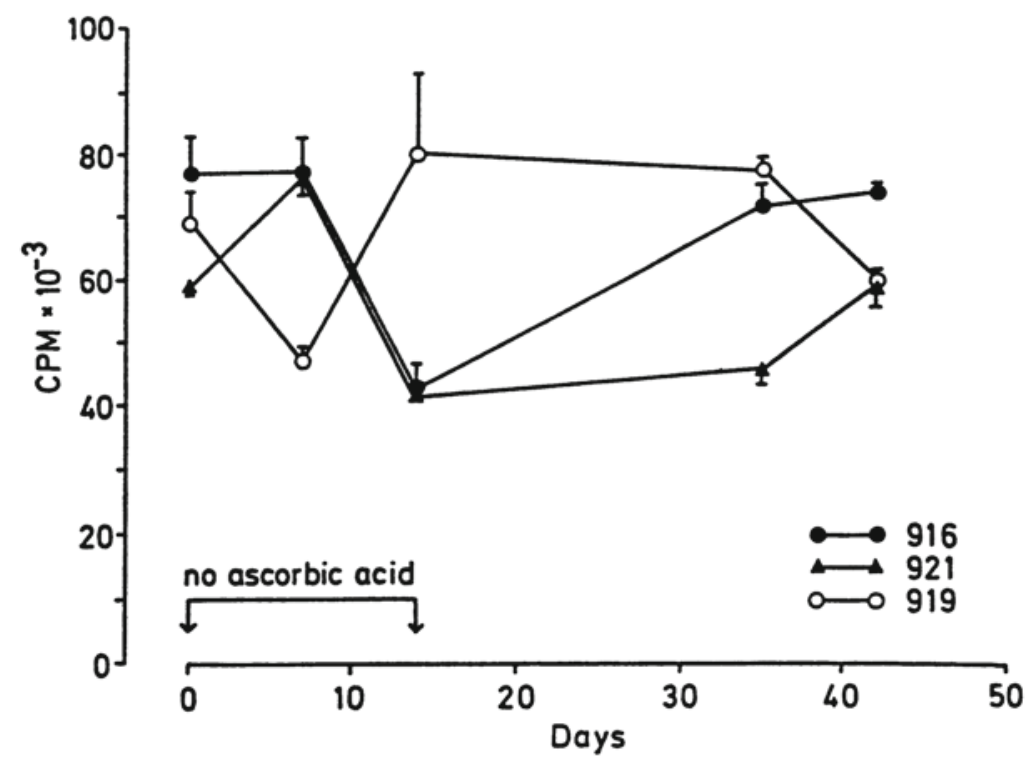

F i g u re 2. Stimulation of blood lymphocytes with Con A (final concentration $40 \mu \mathrm{g} / \mathrm{ml}$ ) during depletion and repletion with ascorbic acid. Each point represents the average of 3 experiments, s.d. is shown as vertical bars. 


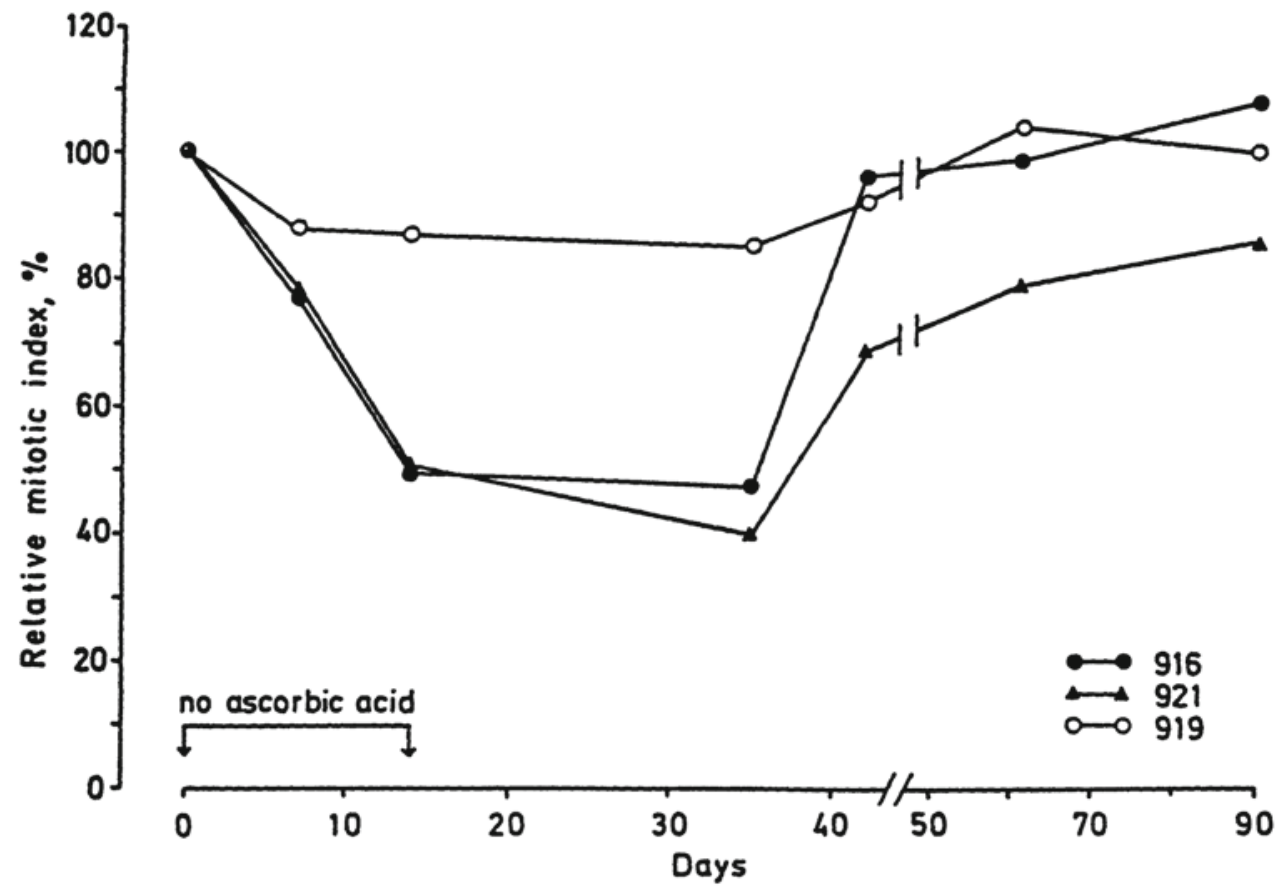

Figure 3. Variations in the relative mitotic index in lymphocytes cultured with PHA during depletion and repletion with ascorbic acid. Each point represents the average of 3 countings, s.d. less than $2 \%$.

tures coincided with the first signs of clinical scurvy while the plasma ascorbic acid content decreased much more rapidly (Fig. 1). A similar time lag was seen in the repletion fase of the experiment, where the plasma ascorbic acid levels had returned to normal within 3 weeks. In contrast the ${ }^{3} \mathrm{H}$-thymidine uptake in the Con A stimulated lymphocytes and especially the relative mitotic index were still significantly lower than before the ascorbic acid depletion of the animals (Figs. 1, 2 and 3). Towards the end of the observation period the response to Con $A$ in the homozygous pigs gradually approached the level seen before ascorbic acid deprivation (Fig. 2).

In contrast to the Con A and PHA response the depletion of ascorbic acid had no effect on PWM stimulation of lymphocytes (Fig. 4). However, when the ascorbic acid supplementation was resumed a temporary increase in the PWM response of lymphocytes from the homozygous pigs was observed. 


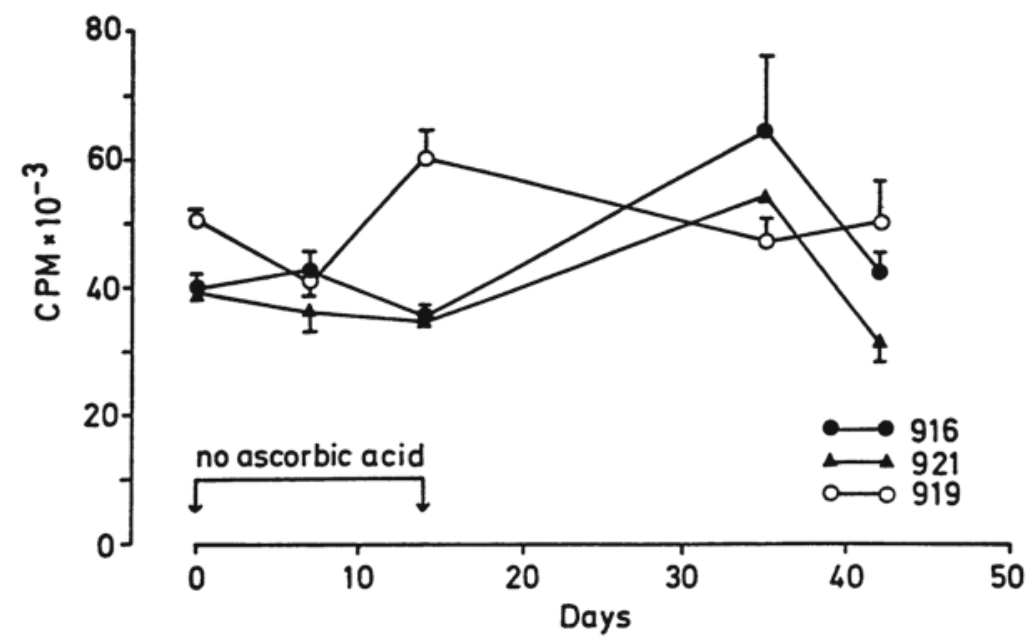

Figure 4. Stimulation of lymphocytes with PWM (final concentration $30 \mu \mathrm{g} / \mathrm{ml}$ ) during depletion and repletion with ascorbic acid. Each point represents the average of 3 experiments, s.d. is shown as vertical bars.

During the experiment no changes were seen in total leucocyte counts in any of the pigs and the relative distribution of lymphocytes also remained constant.

\section{DISCUSSION}

Several investigations have provided evidence that vitamin C has a stimulatory effect on the cell-mediated immune system both when added to lymphocyte cultures in vitro and when administered to animals and man (Panush \& Delafuente 1979, Anderson 1981, 1984). The results of the present study are in agreement with these findings as a reduced response to the mitogens Con A and PHA could be demonstrated in lymphocytes from the vitamin $\mathrm{C}$ deficient pigs (Figs. 2 and 3 ).

Since Con A and PHA primarily are T-cell mitogens also in pigs (Kristensen et al. 1982), this effect seems to involve the Tcell population. Involvement of the T-cell population was further substantiated by the fact that the response to the $\mathrm{B}$ - and T-cell mitogen PWM was not impaired by ascorbic acid depletion (Fig. 4). Reduced T-cell responsiveness has also been demonstrated in scorbutic guinea pigs (Fraser et al. 1980, McMurray 1984) and ascorbic acid injections have been found to enhance 
the sensitivity to T-lymphocyte mitogens in old people with low vitamin C status (Kennes et al. 1983). Furthermore, in ascorbic acid deficient guinea pigs additional T-lymphocyte functions such as the cytotoxic T-lymphocyte (CTL) activity has been shown to be impaired (McMurray 1984).

Ascorbic acid also seems to increase the mitogen response of lymphocytes from normal individuals. As reported by Manzella \& Roberts (1979) incubation of human PBL with ascorbate at a final concentration of $20 \mu \mathrm{g} / \mathrm{ml}$ caused a mean increase of $43 \%$ in the lymphocyte responsiveness to PHA. Likewise a number of reports documents increased T-cell mitogen stimulation of lymphocytes after oral intake of high doses of vitamin $\mathrm{C}$ by normal individuals. Siegel \& Morton (1977) observed that inclusion of ascorbate in the drinking water to mice caused increased lymphocyte reactivity to the mitogens Con A and PHA. Anderson et al. (1980) found enhanced response to both Con A and PHA in healthy humans after daily intake of $1-3 \mathrm{~g}$ of ascorbic acid.

In man ascorbic acid also increases PWM stimulation of lymphocytes whether administered orally or added to cell cultures in physiological concentrations (Panush et al. 1982). As shown in Fig. 4 the PWM response was not influenced by ascorbic acid depletion, but a transitory increase in lymphocyte responsiveness to this mitogen was seen when the pigs were again supplemented with the vitamin.

The mechanisms by which ascorbic acid exerts its stimulatory effect on the cellular immune system are at present not clearly understood. However, several studies in man and animals show influence of vitamin $\mathrm{C}$ on lymphokine production. In normal mice supplementation of the diet with $2500 \mathrm{ppm}$ of ascorbic acid resulted in increased levels of circulating interferon following challenge with murine leukemia virus (Siegel \& Morton 1977). Anderson et al. (1979) also reported that in vitro ascorbic acid treatment of lymphocytes cultured with PHA caused increased release, but not increased synthesis, of the lymphokine Leucocyte migration Inhibition Factor (LIF). Furthermore, there is evidence that ascorbic acid increases the content of cGMP in both B- and T-lymphocytes in vitro (Panush et al. 1983). Since vitamin $\mathrm{C}$ influences the level of certain lymphokines in normal individuals the reduced response in the vitamin $\mathrm{C}$ deficient pigs in this study might be related to decreased production of lym- 
phokines, i.e. interleukin 2 , which is necessary for optimal T-cell response (Kristensen et al. 1982).

Although clinically recognizable vitamin C deficiency in pigs under normal conditions is very unlikely, several studies have shown that ascorbic acid status of swine varies greatly. This is presumably due to genetic factors (cf. Wegger \& Palludan 1984). In some families of pigs the ascorbic acid status might be suboptimal. These observations together with the present results and the demonstration of enhanced cellular immune activity following ascorbic acid administration to normal subjects (cf. Anderson 1984) indicate that supplementation with vitamin $\mathrm{C}$ could have a beneficial effect on the immune responsiveness of swine as well as on other manifestations of life (cf. Gadient \& Wegger 1985).

\section{ACKNOWLEDGEMENTS}

Dr. K. Christensen is thanked for supplying valuable ideas and for helpful discussions. Miss Marianne Winther, Lene Kauffeldt and Mrs. Birgitte Holle are acknowledged for the excellent technical assistance. The study was supported by a grant from the Danish Agricultural and Veterinary Research Council.

\section{REFERENCES}

Anderson, R., R. Oosthuizen \& E. M. S. Gatner: Effects of ascorbate on leucocytes. Part V. Effects of ascorbate and calcium and sodium ascorbate on certain functions of human blood lymphocytes in vitro. S. Afr. med. J. $1979,56,511-515$.

Anderson, R., R. Oosthuizen, R. Maritz, A. Theron \& A. J. van Rensburg: The effects of increasing weekly doses of ascorbate on certain cellular and humoral functions in normal volunteers. Amer. J. clin. Nutr. 1980, 33, 71-76.

Anderson, R.: Ascorbate-mediated stimulation of neutrophil motility and lymphocyte transformation by inhibition of the peroxidase/ $\mathrm{H}_{2} \mathrm{O}_{2}$ /halide system in vitro and in vivo. Amer. J. Clin. Nutr. 1981, 34, 1906-1911.

Anderson, R.: The immunostimulatory, anti-inflammatory and antiallergic properties of ascorbate. In: Advances in Nutrition. Ed. H. H. Draper, Plenum Press, New York 1984, p. 19-45.

Bessey, O. A.: A method for the determination of small quantities of ascorbic acid and dehydroascorbic acid in turbid and colored solutions in the presence of other reducing substances. J. biol. Chem. 1938, 126, 771-784.

Blair, L. \& K. A. Cummins: Effect of dietary ascorbic acid on blood immunoglobulin concentration in dairy calves. J. Dairy Sci. 1984, 67 Suppl. 1, 138-139. 
Brown, R. G.: Ascorbic acid nutrition in the domestic pig. In: Ascorbic Acid in Domestic Animals. Eds. I. Wegger, F. J. Tagwerker \& J. Moustgaard, Royal Danish Agric. Soc., Copenhagen 1984, p. $60-67$.

Christensen, K. \& H. Pedersen: Variation in chromosome number in the blue fox (Alopex lagopus) and its effect on fertility. Hereditas 1982, 97, 211-215.

Fraser, R. C., S. Pavlovic, C. G. Kurahara, A. Murata, N. S. Peterson, K. B. Taylor \& G. A. Feigen: The effect of variations in vitamin $\mathrm{C}$ intake on the cellular immune response of guinea pigs. Amer. J. clin. Nutr. 1980, 33, 839-847.

Gadient, M. \& I. Wegger: Ascorbic acid in intensive animal husbandry. Roche Information Service 1985, 1988, 1-30.

Jensen, P. T., A. Basse, D. H. Nielsen \& H. Larsen: Congenital ascorbic acid deficiency in pigs. Acta vet. scand. 1983, 24, 392-401.

Kennes, B., I. Dumont, D. Brohee, C. Hubert \& P. Neve: Effect of vitamin C supplements on cell-mediated immunity in old people. Gerontology 1983, 29, 305-310.

Kolb, E.: Neuere Erkenntnisse zur Bedeutung und zum Stoffwechsel der Askorbinsäure bei Haustieren (Úbersichtsreferat). (Recent findings on metabolism of ascorbic acid in domestic animals review paper). Mh. Vet.-Med. 1985, 40, 489-494.

Kristensen, F., B. Kristensen \& S. Lazary: The lymphocyte stimulation test in veterinary immunology. Vet. Immunol. Immunopathol. 1982, 3, 203-277.

Lund, C.: Studier over askorbinsyres betydning for svin. Variationer i askorbinsyrekoncentrationen i plasma og væv. (Studies on the importance of ascorbic acid for swine. Variations in ascorbic acid concentration in plasma and tissues). Ph. D. Thesis, Royal Vet. \& Agric. Univ., Copenhagen 1980.

Manzella, J. P. \& N. J. Roberts: Human machrophage and lymphocyte responses by vitamin C. Int. J. Vit. Nutr. Res. 1979, Suppl. 19, virus, ascorbic acid and hyperthermia. J. Immunol. 1979, 123, 1940-1944.

McMurray, D. N.: Cell-mediated immunity in nutritional deficiency. Prog. Food Nutr. Sci. 1984, 8, 193-228.

Panush, R. S. \& J. C. Delafuente: Modulation of certain immunologic responses by vitamin C. Int. J. Vit. Nutr. Res. 1979, Suppl. 19, $179-199$.

Panush, R. S., J. C. Delafuente, P. Katz \& J. Johnson: Modulation of certain immunologic response by vitamin C. III. Potentiation of in vitro and in vivo lymphocyte responses. Int. J. Vit. Nutr. Res. 1982, Suppl. 23, 35-47.

Panush, R.S., P. Katz, G. Powell \& L. Somberg: Immunopharmacologic effects of vitamin C. IV. Perturbation of mononuclear cell cyclic nucleotides. Int. J. Vit. Nutr. Res. 1983, 53, 61-67.

Prinz, W., R. Bortz, B. Bregin \& M. Hersch: The effect of ascorbic acid supplementation on some parameters of the human immunological defense system. Int. J. Vit. Nutr. Res. 1977, 47, 248-257. 
Siegel, B. V. \& J. I. Morton: Vitamin C, interferon and the immune response. Int. J. Vit. Nutr. Res. 1977, Suppl. 16, 245-265.

Wegger, I. \& B. Palludan: Ascorbic acid status of swine. Genetic and developmental variations. In: Ascorbic Acid in Domestic Animals. Eds. I. Wegger, F. J. Tagwerker \& J. Moustgaard, Royal Danish Agric. Soc., Copenhagen 1984, p. 68-79.

Yen, J. T. \& W. G. Pound: Effect of dietary vitamin $\mathrm{C}$ addition on performance, plasma vitamin $\mathrm{C}$ and hematic iron status in weanling pigs. J. Anim. Sci. 1981, 53, 1292-1296.

\section{SAMMENFATNING}

\section{Mitogen stimulering af lymfocyter fra grise med arvelig vitamin $C$} mangel.

Arvelig betinget vitamin C mangel, der sandsynligvis er betinget af et autosomalt recessivt gen, er fornylig beskrevet hos svin. Homozygoter er i modsætning til heterozygoter og normale grise ude af stand til at syntetisere askorbinsyre. Stimulering af lymfocyter fra perifert blod med mitogener blev foretaget hos tre grise fra et kuld, to homozygoter og en heterozygot for genet for vitamin C mangel, dels under askorbinsyremangel dels $\mathrm{i}$ en periode, hvor de homozygote dyr fik askorbinsyre tilf $\varnothing$ rt. Seponering af askorbinsyretilf $\varnothing$ rsel medf $\emptyset$ rte et hurtigt fald i plasmaets askorbinsyreindhold hos de vitamin $\mathrm{C}$ afhængige grise. Lymfocyternes reaktion på stimulering med concanavalin A (Con A) og fytohæmagglutinin (PHA) aftog langsommere og nåede et minimum samtidigt med fremkomsten af de første kliniske symptomer på skørbug. Efter genoptagelse af vitamin $\mathrm{C}$ tilf $\varnothing \mathrm{rslen}$ steg askorbinsyrekoncentrationen i plasma hurtigt til normale værdier, medens f $\varnothing$ lsomheden af lymfocyter overfor Con A stimulering kun gradvist nærmede sig de initiale værdier. Samtidigt sås en forbigående stigning i lymfocyternes f $\varnothing$ lsomhed overfor pokeweed mitogen (PWM). Disise funds mulige betydning for normale svins cellulære immunsystem diskuteres.

(Received June 25, 1986).

Reprints may be requested from: B. Kristensen, the Department of Animal Genetics, Royal Veterinary and Agricultural University, Bülowsvej 13, DK-1870 Frederiksberg C, Denmark. 